\title{
STRUCTURAL GEOSTRATEGY OF UKRAINE CONCERNING POST-SOVIET COUNTRIES IN NEW GEOPOLITICAL REALITIES
}

\author{
Vladyslav MORHATSKYI \\ Ivan Franko National University of Lviv, Ukraine \\ vladkulykivka@ukr.net
}

\begin{abstract}
This article is a brief analysis of the trends of political and geographical processes in the post-Soviet countries, theoretical and methodological principles of constructive geostrategy are defined and the stages of their course are outlined. Particular attention is paid to the last mentioned, because its isolation was carried out through the Russian intervention into Ukraine and the strengthening of ties within the Eurasian Economic Community.Moreover, relations with each country are considered. In order to do this, the regions of interaction on the basis of geographic and geopolitical factors have been identified. These are, in particular, the regions of the Eastern Baltic (the states of the EU and NATO) and the GUAM (regional association of countries, most of which are Associate Members of the EU). The Russian Federation is allocated to be a separate region as a regional leader among the post-Soviet countries and the most complicated for us in the relations of the subject with its neo-imperial geopolitical ambitions. What is more, in a separate group are the Allied states of Russia (Belarus and Armenia). And lastly, Central Asia consistent in all respects is highlighted. Analysis of relations with all countries is performed in three dimensions: geopolitical, geoeconomic and geocultural. After that a constructive geostrategy which primarily relies on Ukrainian interests, but is acceptable to each subject, has been developed. Significant emphasis was put on maintaining positive relations and existing positions in the countries markets. This does not apply to Russia, with which relations will remain cool in the future, and trade and economic cooperation requires immediate diversification to ensure geopolitical interests.

Key words: constructive geostrategy, post-Soviet countries, states of the Eastern Baltic, GUAM countries, Russian Federation, geopolitical allies of Russia, the states of Central Asia.
\end{abstract}

DOI: https://doi.org/10.17721/2413-7154/2019.82.34-49

UDC: $911.3: 32$

Received: December 3, 2019.

Revised: December 19, 2019.

Accepted: December 24, 2019.

\section{КОНСТРУКТИВНА ГЕОСТРАТЕГІЯ УКРАЇНИ ЩОДО ДЕРЖАВ ПОСТРАДЯНСЬКОГО ПРОСТОРУ В НОВИХ ГЕОПОЛІТИЧНИХ РЕАЛІЯХ}

\section{Владислав МОРГАЦЬКИЙ}

\author{
Львівський національний університет імені Івана Франка, Україна \\ vladkulykivka@ukr.net
}

\begin{abstract}
Анотація: У статті здійснено короткий аналіз тенденцій політико-географічних процесів на пострадянському просторі, визначено теоретико-методологічні засади конструктивної геостратегії та виділено етапи їх перебігу. Головну увагу приділено останньому, адже їхнє дослідження здійснено з причини російської інтервенції в Україну та посилення зв'язків в межах Євразійського економічного співтовариства. Надалі розглянуто відносини з кожним суб'єктом простору. Для цього виділено регіони взаємодії на основі географічних й геополітичних чинників. Це, зокрема, регіон Східної Балтії (держави входять до ЄС та НАТО), держав ГУАМ (регіонального об'єднання країн, більшість з яких - асоційовані члени ЄС). Окремим регіоном виділено Російську Федерацію як регіонального лідера пострадянського простору та найважчого для нас у стосунках суб'єкта зі своїми неоімперськими геополітичними амбіціями. До того ж, в окремій групі перебувають держави-союзниці Росії (Білорусь та Вірменія). І, насамкінець, виділено закономірну в усіх планах Центральну Азію. Розгляд відносин з усіма країнами здійснено у трьох вимірах: геополітичному, геоекономічному та геокультурному. Після їх аналізу розроблено конструктивну геостратегію, яка, головно, спирається на українські інтереси, проте $є$ прийнятною для кожного суб'єкта. Вагомий акцент поставлено на збереженні позитивних відносин та існуючих позицій на ринках країн. Це не стосується Росії, з якою стосунки матимуть більш деструктивний характер і надалі. Торгово-економічна співпраця з державами СНД та Східної Балтії вимагає негайної диверсифікації для забезпечення геополітичних інтересів.

Ключові слова: конструктивна геостратегія, пострадянський простір, держави Східної Балтії, країничлени ГУАМ, Російська Федерація, геополітичні союзники Росії, держави Центральної Азії.
\end{abstract}




\section{Постановка проблеми}

Геополітичні дослідження набувають все більшої актуальності в нових суспільно-політичних умовах пост-радянського простору. Для вироблення повно-цінних міждержавних стосунків важливим $€$ комплексне висвітлення усіх аспектів взаємодії геополітичних, геоекономічних та геокультурних. Потреба дослідження геополітичних стратегій держав пострадянського простору відбулася 3 активізацією агресивної геополітики Російської Федерації (РФ). Анексія Криму та підтримка бойовиків квазіреспублік “ДНР/ЛНР” призвела до порушення цілісності України і погіршення українсько-російських відносин на всіх рівнях. Формування конструктивної геостратегії щодо країн колишнього Радянського Союзу повинне стати об’єктом дослідження науковців різних галузей, адже пострадянський простір залишається сферою міждержавних торгово-економічних, культурногуманітарних i, частково, військово-політичних інтересів України. Усвідомлення особливостей внутрішньої та зовнішньої геополітики у досліджуваних пострадянських держав дозволить розробити комплексне бачення співпраці між Україною та ними, 3 намаганням якнайкраще задовільнити інтереси кожного суб'єкта відносин.

\section{Аналіз останніх досліджень та публікацій}

Після подій 2013-2014 рр. в Україні розпочався процес перегляду відносин з багатьма державами. Велику кількість досліджень здійснено істориками, політологами, фахівцями у галузі міжнародних відносин, а також урядовими та неурядовими дослідницькими організаціями, зокрема Національним інститутом стратегічних досліджень, Інститутом всесвітньої історії НАН України, Інститутом світової політики, Інститутом політичних i етнонаціональних досліджень ім. І. Ф. Кураса та іншими. Більшість наукових праць присвячено двостороннім відносинам, зокрема О. Бетлій, А. Гайдара, Л. Мандзій, I. Мельничука, Т. Орлової, О. Кондратенка та багатьох інших. Географічні аспекти двосторонніх відносин висвітлені у публікаціях М. Дністрянського, С. Сонька, Ю. Кисельова, В. Стафійчука.

\section{Мета статті}

Метою статті є висвітлення характеру відносин України 3 державами пострадянського простору y нових геополітичних умовах та формування конструктивної геостратегії щодо збереження їх збалансованості та взаємовигоди.

\section{Виклад основного матеріалу}

Зі здобуттям Україною незалежності розпочався процес їi міжнародно-правового становлення як європейської держави. Актуальною стала потреба

(C) Vladyslav Morhatskyi налагодження відносин незалежної України 3 новими незалежними державами (ННД), які утворилися з розпадом Радянського Союзу. Варто зауважити, що становлення відносин відбувалося по-різному, зокрема, під впливом інтеграційних, дезінтеграиійних і реінтеграційних тендениій.

Дезінтеграційна тенденияія пов'язана, перш за все, 3 існуванням СНД як “інструменту розлучення”. Інтеграційна тенденція є основою бажання регіональних чи субрегіональних держав розбудувати альтернативні схеми багатосторонньої взаємодії (СНД, ГУАМ, Центрально-Азійське співробітництво). Реінтеграційна тенденція полягає в оптимальному використанні кожної із складових “народногосподарського комплексу "Радянського Союзу або ж його регіонів [31,с. 88].

Загалом, політико-географічні процеси на пострадянському просторі ми виділяємо у такі групи:

1. Формування міжнародно-правового статусу держав на пострадянському просторі (1991-1995 pp.);

2. Початок реалізації Росією геостратегіi регіонального лідерства на пострадянському просторі (крім держав Східної Балтіі) (1996-2003 рр.);

3. Демократична та проєвропейська трансформачія держав 3 диверсифікацією зовнішньоекономічної діяльності на пострадянському просторі (2004-2010 рр.);

4. Реалізачія проектів інтенсифікаиіi економічних зв'язків у межах СНД та формування проекту Свразійської інтеграції (2010 - 2013 рр.);

5. Остаточне підтвердження сутності сучасної російської геополітики з розумінням можливих наслідків для всього пострадянського простору (2014 рік - наш час) [31, с. 95-98].

У світовій i національній науковій та публіцистичній літературі останнього десятиріччя утвердився термін “пострадянський простір”, який є зручним та політично нейтральним для позначення території колишнього СРСР. На думку української дослідниці Тетяни Орлової, “пострадянський простір - насамперед особлива соціальна і політична реальність, суперечлива цілісність котрої зумовлена спільністю попереднього розвитку народів, що ¥іi становлять, i особливо єдністю радянського соціалістичного етапу їхньої історії' [19, с. 449].

Російські дослідники захищають і використовують його у своїх працях, які відображають геостратегічні інтереси Росії на фаховому рівні. Існує думка щодо недоцільності вживання цього терміну в науковому обігу. Причинами цього $є$ заангажованість у руслі російської постімперської ідеології. Ігор Мельничук вважає, що цей концепт на сучасному етапі “не існує як цілісний політико-географічний регіон, оскільки у ньому присутні достатньо глибокі та принципові відмінності між державами, які входили до складу колишнього Радянського Союзу”. Вагомим аргументами щодо цієї думки $є$ різноманітність 
соціально-економічних і політичних укладів, які притаманні ННД; відмінність зовнішньополітичних цілей та орієнтирів; відсутність між більшістю пострадянських держав сучасних комунікацій (переміщення капіталу, товарів, робочої сили i т. д.); відсутність вигідних умов проектів інтеграції, які би приваблювали всі держави регіону через намагання Росії нерівноправного об'єднання [15,c. 28 - 30]. Сам же дослідник під пострадянським простором розуміє “дванадцять держав - колишніх республік СРСР (за винятком країн Балтії), які залучені до інтеграційних процесів на теренах колишнього Радянського Союзу та, на даний час, не входять до складу НАТО та ЄC" [15,c. 30]. Попри чітку різноманітність геополітичних векторів та інтеграційних проектів держав СНД та Східної Балтії між ними збереглись транспортнологістичні зв'язки (автомобільне, залізничне та трубопровідне сполучення) i торговельноекономічні взаємовідносини. В геополітичному плані проблемою відносин є наявність російських меншин, які мають вплив на українські громади пострадянського простору. Це позначається на внутрішніх політико-географічнихпроцесах держав, особливо завдяки застосування "м'якої сили" впливу Російської Федерації. 3 вищезазначеного переходимо до свого визначення досліджуваного поняття: пострадянський простір - політикогеографічне утворення п'ятнадцяти республік колишнього СРСР, які по-різному перебувають у геополітичних, геоекономічних, геокультурних зв'язках та мають спільні проблеми пов'язані із радянським минулим та побудовою національних держав [18, с. 95 - 96].

Обмеженість геостратегічного мислення спонукає до необхідності синтезу ідеалізму та реалізму в геополітичних підходах, якого, зокрема, можна досягти шляхом прагматизації ідеалістичних принципів та поступового усунення 3 реальної геополітики експансіоністських та гегемоністських установок. Геополітика узгодження інтересів усіх держав повинна забезпечуватися реальним механізмом взаємин та впливу. Саме на такий принцип має орієнтуватися гармонізація територіально-політичних взаємин та баланс геополітичних процесів в рамках конструктивної зрівноваженої геополітики. 3 огляду на те, що основою зовнішньої політики держав завжди залишатимуться національні інтереси, то в сучасних умовах актуальними $€$ проблеми вироблення механізмів їхнього узгодження, який має стати предметом зрівноваженої конструктивної геостратегіï [9, с. 322 -326].

Початково геостратегія була інструментом виборювання прямого, насамперед військового i політичного, контролю над визначеними територіями. Сучасне трактування терміну “геостратегія" грунтується на стратегічних національних інтересах держави та формулює аргументованість їх доцільності в міжнародних відносинах з іншими суб'єктами [11, с. 120-121]. В плані генезису визначення терміну є зацікавлення держав та формування вектору геостратегічних інтересів. Із позиції української геополітичних орієнтирів актуально залишається співпраця пострадянським простором.

Виходячи із цих раціональних поглядів вище наведених досліджень, виводимо визначення зрівноваженої конструктивної геостратегії як “обгрунтованої в геополітичному, геоекономічному тагеокультурномувимірістратегїміждержавного співробітництва на основі вироблення механізму узгодження інтересів та взаємної вигоди”. Важливо, щоб ці складові доповнювали, а не суперечили одна одній, результатом чого, замість тяжко контрольованого прагнення максимального задоволення своїх національних інтересів, буде встановлення рівноваги або балансу сил, що так потрібно нашій державі та світу загалом.

Для реалізації конструктивної геостратегії потрібно розуміти, як формуються стосунки України з іншими державами саме після суспільнополітичних перетворень у 2013 - 2014 рр. та як вони відображаються на співпраці. Основний акцент ми зосередимо на трьох визначених нами вимірах: геополітичному (відношення урядів держав пострадянського простору до порушення цілісності України, підтримка на міжнародній арені, особливості політичних контактів); геоекономічному (динаміка зовнішньоторговельного обігу товарів і послуг, наявність обмежень щодо торгівлі); геокультурному (особливості культурногуманітарного співробітництва, діяльність культурних товариств України у ННД та лояльність державної влади до їх функціонування). Для цієї характеристики для нашої держави ми виділили такі групи взаємодії як: країни Східної Балтії, держави ГУАМ, Російська Федераиія (як окремий напрямок), держави-союзниці Росії (Білорусь та Вірменія), країни Центральної Азї [18, с. 96].

Тісні міждержавні політико-дипломатичні зв'язки України з Естонією, Латвією та Литвою встановлено за часів формування УНР та незалежних Балтійських країн. Надалі співробітництво інтенсифікувалося у післявоєнний період в межах Радянського Союзу та його «народногосподарського комплексу». Крім того, сформувалися відносно невеликі діаспори, а також соціально-культурні відносини. На сьогодні ці суб'єкти - члени ЄС та НАТО, що, власне, й обумовлює пріоритетність співпраці з ними як державами, які змогли подолати усі проблеми пострадянського періоду та утвердити національно-демократичні тенденції розвитку.

Головним партнером на сучасному етапі виступає Литва. Уряд цієї країни є “адвокатом" нашої держави у європейських структурах. Показово, що Угода про Асоціацію з Європейським Союзом (СС) має такий результат завдяки дипломатикополітичній підтримці саме литовського боку, адже всі розуміють - Росія не повинна стати імперією, яка диктуватиме свої умови. Визнання агресії було миттєвим, крім того, минулий і теперішній президент країни на цьому наголошує постійно. Для посилення військово-політичної підтримки було 
створено ЛитПолУкрбриг. У геополітичному плані Литва стала стратегічним партнером не тільки серед країн Балтії, але й усього ЄС. Зокрема, діє постійна комісія з питань європейської інтеграції, Міжурядова комісія $з$ питань торгово-економічного та науковотехнічного співробітництва, ділова рада тощо. На жаль, бізнесмени цієї країни не поспішають виходити на наш ринок через недосконалість законодавчої бази [4, с. 12-13]. Основними статтями українського експорту є продукція агропромислового комплексу (АПК) і харчової промисловості, машинобудування, деревина і вироби 3 неї. Основні статті імпорту товарів - нафтопродукти, пластмаси і полімерні речовини [4, с. 21-22]. Головним стратегічним замислом залишається транспортний маршрут "Viking" між портами Чорноморськ та Клайпеда. Це амбітний проект залізниць України, Білорусі та Литви 3 перевезення вантажів від Чорного до Балтійського моря, призначений для економності перевезення із Азії до Скандинавських країн [4, c. 25-26]. Що стосується культурно-гуманітарного співробітництва, варто відзначити велику прихильність самого литовського народу до українського, його співпереживання за долю України та щиру підтримку ii європейського розвитку. Урядом балтійської країни виділяються кошти на лікування воїнів ООС, а також надаються навчальні стипендії для їх дітей [4, с. 33-37]. Варто згадати також про те, що українська меншина в Литві та литовська меншина в Україні є доволі нечисленними: литовців в Україні є близько 7 тисяч, а українців в Литві - 16423 особи. Для порівняння, до розпаду СРСР кількість наших співвітчизників становила майже 45 тисяч осіб. Причинами зменшення $€$ зміна поколінь, інтеграція в чисельнішу російську діаспору та відсутність масової української міграції у новітній період. Державна національна політика Литви враховує інтереси представників національних меншин. Основним напрямом роботи Громади українців Литви виступає культурно-просвітницька діяльність, відродження і забезпечення національної самобутності [10, с. 121].

Латвія також $є$ надійним політичним та економічним партнером України. 3 початком військових дій у нашій країні керівник МЗС заявив: "Російське вторгнення в Україну Радбез ООН повинна розцінити як акт агресії”. У 2015 р. Латвія була головуючою у Раді Свросоюзу і намагалася

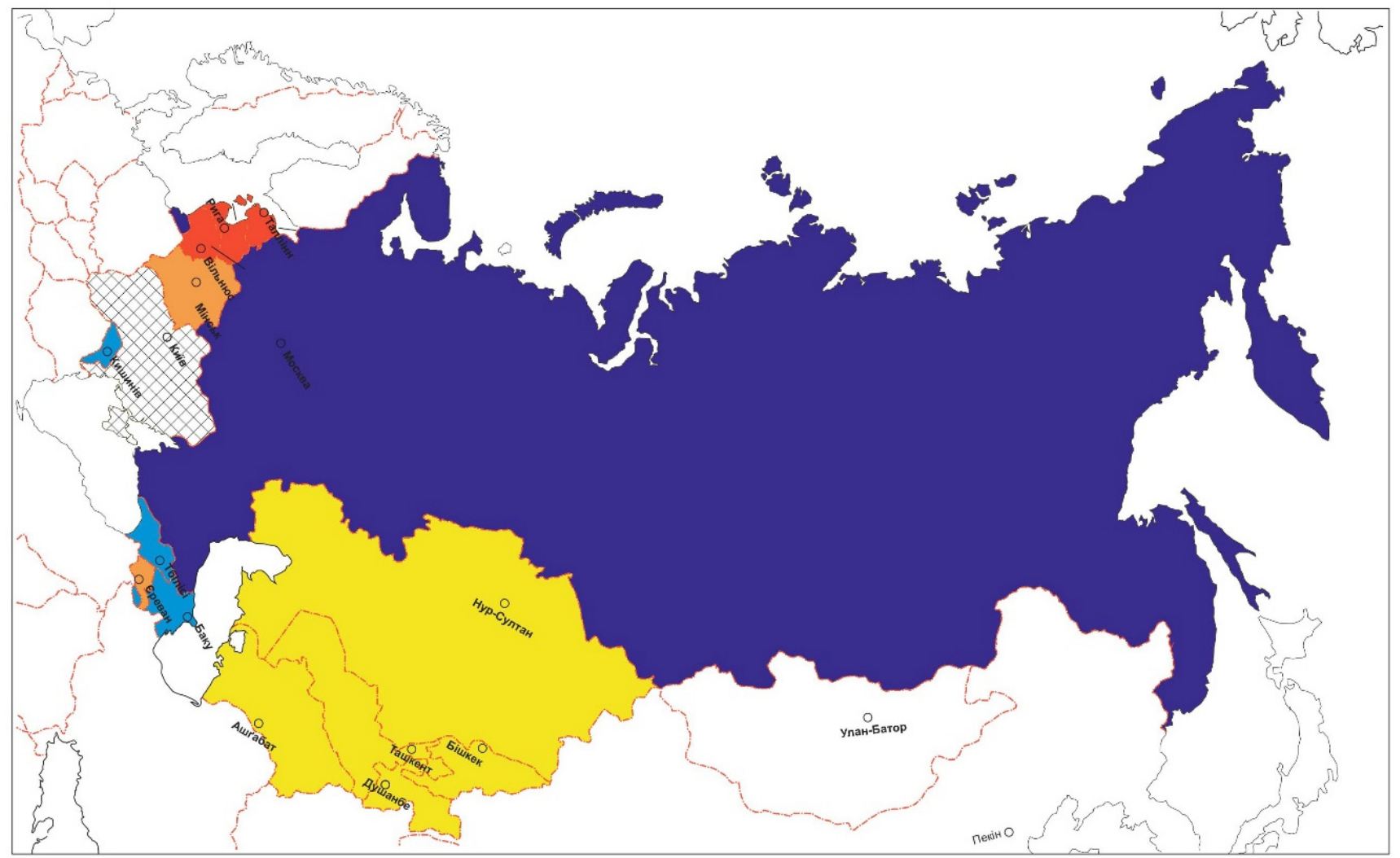

Умовніпозначення

Групи зовнішньої геополітичної співпраці України з державами

- Нур-Султан столиці держав

1.

Масштаб 1: 45000000 пострадянського простору

країни Східної Балтії

держави ГУАМ

Російська Федерація

держави-союзниці Росії

країні Центральної Азії

Рис. 1. Групи геополітичної взаємодії України із державами пострадянського простору 
реагувати на події стримано. Наголошувалося, що постачання зброї Україні - крайній захід. Але щодо санкцій сумнівів ніяких не було. Однозначно, керівництво країни буде діяти у руслі позиції Західного світу, але наявність великої частки росіян та російськомовного населення 3 можливістю внутрішньополітичної дестабілізації стримуватиме різкість антиросійської позиції уряду [14, с. 403404]. В контексті реалізації геоекономічних контактів керівництву держав цікаве формування Балтійсько-Чорноморської транспортної вісі. Для сталості відносин створена Рада ділової співпраці, яка повинна сприяти роботі Міжурядової комісії 3 питань економічної, промислової та науковотехнічної співпраці. Основними товарами, які Україна імпортує з Латвії, є продукція хімічного виробництва та суміжних галузей, транспортні засоби, текстильні матеріали та текстильні вироби; машини та механізми електрообладнання; целюлоза, папір, картон, продовольчі товари. Зі свого боку Латвія імпортує з України метали та металовироби, мінеральні продукти, транспортні засоби [26; 32, c. 93-96]. Культурно-гуманітарна співпраця на офіційному рівні розпочалася в 1932 р. і динамічно розвивалася у післявоєнний період, у зв'язку 3 проходженням військової служби та скеруванням на роботу спеціалістів. За результатами переписів населення 2000 і 2011 рр. у країні проживало 63644 та 45798 українців відповідно. Більшість із них мешкає у Ризі. Попри певну культурну активність, українці не прагнуть до консолідації. Незважаючи на збільшення їх чисельності завдяки новим трудовим мігрантам, іде постійна тенденція до депопуляції етнічної групи. Причиною негативних ознак є зросійщення українців, слабка інтеграція в латвійське суспільство, проблеми 3 набуттям латвійського громадянства, зміна етнічної належності [32, с. 148-149; 10, с. 121].

Естонія також залишається активним зовнішньополітичним партнером України у питаннях поглиблення взаємодії з СС та НАТО. Політична еліта відразу ж засудила агресивну геополітику Росії щодо України та неприпустимість порушення державного суверенітету. Офіційний Таллінн підтримав укладення Угоди про асоціацію, створення Зони вільної торгівлі та спрощення візового режиму між Україною та $Є С$, а також із розумінням сприйняв позицію нашого уряду щодо подальшої співпраці 3

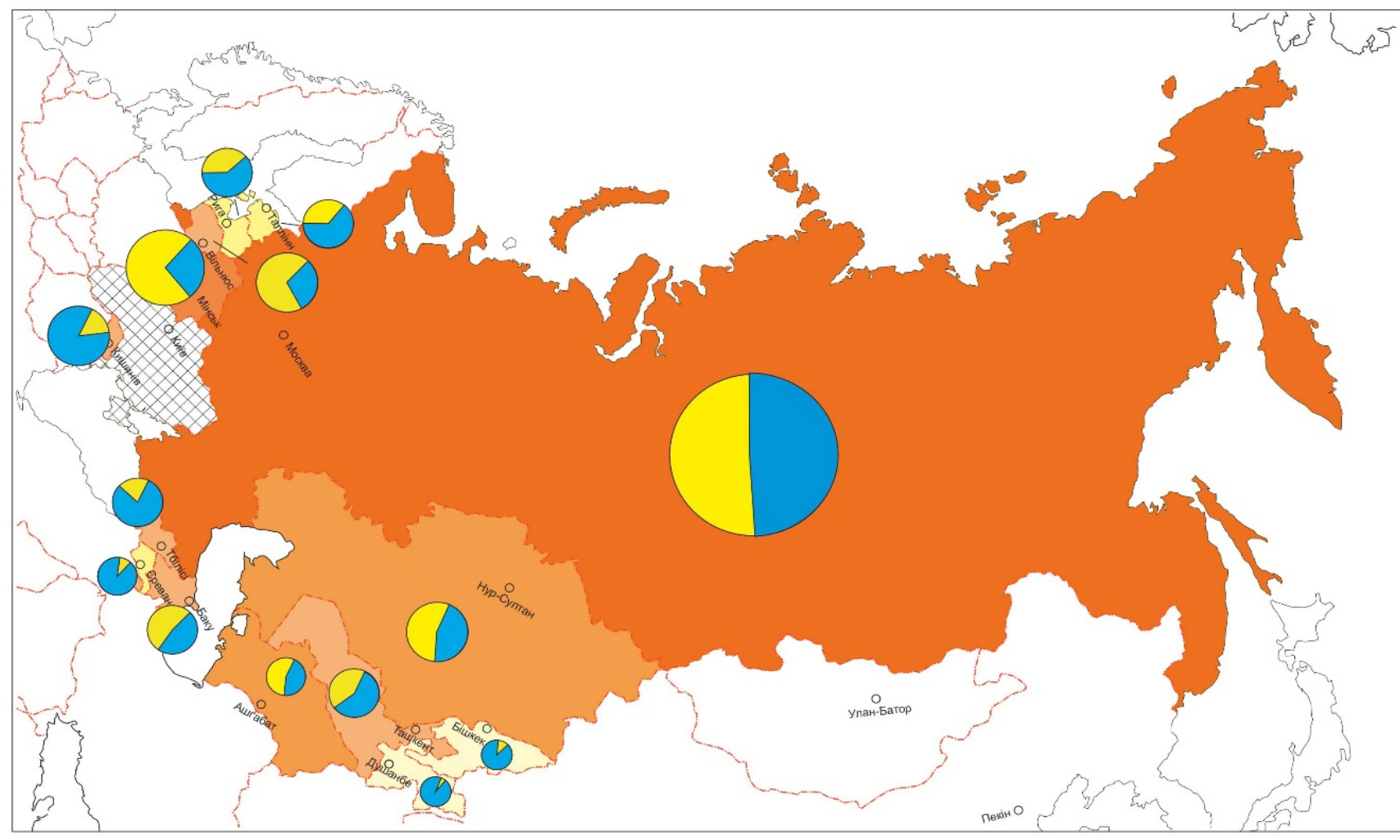

Умовні позначення
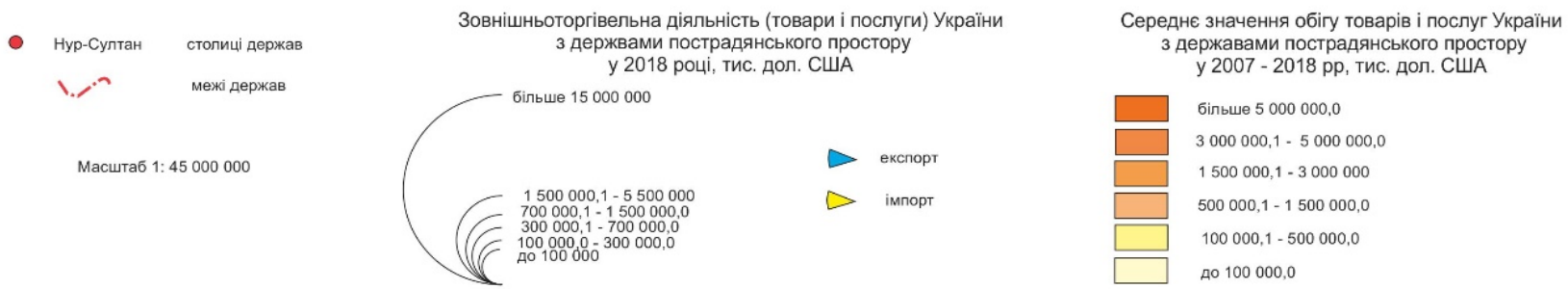

Рис. 2 Зовнішньоекономічна діяльність України з державами пострадянського простору, складено за [19] 
Північноатлантичним Альянсом [14, с. 205]. Щодо зовнішньоекономічної діяльності, то основними товарами експорту були чорні метали та вироби 3 них, деревина і вироби з деревини, електромашини, реактори ядерні, котли, машини, залізничні локомотиви, продукція харчової промисловості. Групи імпорту товарів до України представлені продуктами харчування, мінеральним паливом, нафтою i нафтопродуктам, фармацевтичною продукцією [23]. 3 погляду геокультурної співпраці важливою залишається підтримка естонським народом українського у побудові справжнього демократичного суспільства. Згідно 3 переписом населення 2011 р., в Естонії налічується 22573 наших співвітчизників. Нині в країні існує понад два десятки культурно-громадських організацій українців. Майже всі вони є членами двох потужних структур - Конгресу українців Естонії та Асоціації українських організацій Естонії. Останнім часом серед українських студентів стають популярними естонські 3ВО, які дають освіту високого рівня. Головна ж проблема - відсутність навіть класів навчання українською мовою [33, с.160-165].

Пошук альтернативних моделей розвитку та інтеграції на пострадянському просторі став актуальним у середині 90-х рр., коли стало зрозуміло, що Росія поступово прагне перетворити СНД та ОДКБ на зону свого геостратегічного впливу, не враховуючи відповідних інтересів інших суб'єктів. Тому поява регіонального об'єднання ГУАМ стало закономірною відповіддю. Географічно воно роз'єднано Чорним морем. Інколи в торговоекономічному та культурно-гуманітарному плані зв'язки зазнають стагнації, але перспектива цілісного становлення у сучасних геополітичних реаліях досить змістовна [13, с. 48-49].

Найважливішим партнером у даній групі слід назвати Грузію. Політичні еліти країни як ніхто розуміють, що таке порушення територіальнополітичної цілісності, спровокованої впливом Росії. Тому реакція на українські події 2014 р. була закономірною - повне засудження дій російського керівництва. Парламент тричі приймав резолюцію на підтримку єдності України. Крім того, була надана суттєва гуманітарна допомога. Грузинські політики були запрошені для реформування державної системи, а екс-президент Міхеіл Саакашвілі став губернатором Одещини (є різні оцінки його діяльності), що стало однією з причин інертності співпраці між чинними владами країн. Надію на новий виток взаємин дає підписана влітку 2017 р. Декларація про встановлення стратегічного партнерства. У цьому та інших підписаних документах сторони домовилися не лише про співпрацю в економіці, освіті, транспортній сфері, спільні навчання українських i грузинських військових, а й про координацію зусиль на міжнародній арені для захисту територіальної цілісності України та Грузії. Важливим стало започаткування діяльності новоствореної Стратегічної ради високого рівня. На сьогодні актуальною $\epsilon$ координація дій та обмін досвідом у зв'язку 3 дією в обох країнах Асоціації з СС [7,с. 7-11]. В контексті геоекономіки важливим $є$ налагодження системного транспортного сполучення між портами держав для формування ЧорноморськоКавказького шляху ГУАМ. Основними товарними позиціями експорту $є$ чорні метали та вироби 3 них, продукція агропромислового комплексу та харчової промисловості, тютюн, продукція хімічної промисловості. Імпортуємо ж із Грузії феросплави, алкогольні вироби, мінеральні води [7, с. 22 $29 ; 23] . У$ геокультурному вимірі спостерігається підтримка європейських цінностей обома народами. Грузини брали активну участь у Революції Гідності і досі присутні у зоні бойових дій на боці України. Однак взаємні симпатії двох народів зберігаються не завдяки, а всупереч гуманітарній політиці України та Грузії. Майже відсутні академічні та студентські обміни, а співпраця між культурними та освітніми інституціями залишається непомітною. Позитивні тенденції мають лише зв'язки неурядових організацій. Згідно перепису 2014 р. у Грузії (без урахування Абхазії та Південної Осетії) проживало 6034 українці, половина 3 них - у Тбілісі. На жаль, шкільництво не представлене жодним українським класом, що суттєво послаблює «м'яку силу» у дружній державі [10, с. 69; 23, с. 41].

Значним потенціалом володіють відносини 3 Азербайджаном. Уряд південнокавказької республіки намагається лавірувати між інтересами Росії, Заходу та Туреччини. Тому реального партнерства між державами немає, а панівним є торгово-економічний прагматизм. Азербайджан втратив свої території зі створенням НагірноКарабахського квазіутворення, яке безпосередньо підтримується Вірменією й опосередковано Росією. Представники країни проголосували “за” Резолюцію Генеральної Асамблеї ООН про територіальну цілісність України. До літа 2016 р. спостерігався певний застій відносин через відсутність контактів на рівні глав держав. Після зустрічі лідерів було заявлено про збільшення прагматичності відносин з перспективою розвитку Чорноморсько-Кавказо-Центральноазійського шляху, а також розширенням імпорту Україною нафтопродуктів [2, с. 10-15]. Таким чином, основою політичних відносин стали геоекономічні аспекти взаємодії як на двосторонньому рівні, так і в рамках ГУАМ. Структуру експорту України до республіки формували поставки чорних металів, тютюну i промислових замінників тютюну, деревини та виробів із дерева, продуктів харчової промисловості. В імпорті 3 Азербайджану були такі товари: паливні, мінеральні, нафта і продукти їі перегонки, пластмаси та полімерні метали, органічні хімічні сполуки та інше [21]. У геокультурному плані азербайджанці мають світський уклад державного будівництва, що відображається в інтенсифікації зв'язків не тільки 3 пострадянським простором чи 3 азійським світом, але вагому роль відіграє кооперація 3 європейськими країнами. Україна важлива складова пострадянської реальності, давній партнер та держава 3 європейською орієнтацією. 
Азербайджанці сприяють навчанню студентів в українських 3ВО. Водночас посилюється взаємодія із навчальними закладами республіки, здійснюється активне залучення туристів до України і навпаки. Щодо української діаспори, то її утворення датують XIX ст. - початком нафтового буму в країні. Збільшенню чисельності наших співвітчизників сприяли процеси природного приросту, евакуації українців у роки Другої світової війни, розподілу спеціалістів на роботу (особливо нафтопереробної галузі). За переписом 2009 р. налічується 21500 українців, які, головно, проживають у Баку [10, с. 63 64]. Діяльність діаспори регулюється Українським конгресом Азербайджану. Активними у соціальноекономічному плані залишається азербайджанці, що проживають у нашій країні.

Молдова як безпосередній сусід ніколи не випадала із зони контактів на всіх рівнях. Після суспільно-політичних подій в нашій державі та російської інтервенції уряд Республіки засудив ці дії та почав налагоджувати контакт з новою українською владою. Після виборів в Україні відбулася підтримка молдовських проєвропейських кандидатів на виборах кінця 2014 р. Політичними точками дотику подальшої співпраці стала торгівля, розбудова транспортної і прикордонної інфраструктури, урегулювання Придністровського питання, a також вирішення проблем делімітації і демаркації кордону, екологічних проблем Дністра. Наразі ж головна проблема взаємовідносин - утвердження відверто проросійських сил у парламенті та формування їх сильної позиції порівняно 3 проєвропейськими об'єднаннями $[5$, с. 4-8; 8, c. 4-6]. Основним інструментом для налагодження економічної співпраці між країнами є Міжурядова змішана комісія 3 питань торгово-економічного співробітництва. За останні чотири роки негативним моментом стало збільшення митних тарифів на продукти харчування та цемент, що завдало збитків українським підприємствам. Ці питання вирішувалися на рівні глав урядів. У сфері енергетики держави мають за мету виробити та реалізувати план спільних дій $з$ інтеграції енергетичних систем до європейської мережі системних операторів передачі електроенергії. Головними статтями експорту до Молдови залишається продукція аграрного сектору, цигарки, вироби з металу, продукція будівельної та хімічної галузей. Імпортується в Україну продукція рослинництва, вино, етиловий спирт. Суттєво збільшився імпорт пшениці, кукурудзи, бавовняних тканин [28]. В геокультурному вимірі $€$ проблема 3 проросійськи налаштованими спільнотами, які скептично ставляться до свого європейського уряду, неоднозначно оцінюють українські події. Уряд України постійно намагається сприяти культурноосвітнім зв'язкам, популяризації вітчизняних артистів, налагодженню академічних обмінів. Неоднозначну взаємну оцінку викликає ліквідація у середньої та старшої шкільної ланки навчання у закладах середньої освіти національною мовою. Чисельність українців Молдови надзвичайно знижується. Якщо згідно з переписом 2004 р. кількість наших співвітчизників становила 282406 (8,4\%) осіб, то вже у 2014 р. зменшилася до 111726 осіб, тобто у 2 рази. За переписом 2004 р. самопроголошеного Придністров'я - 160069 осіб. Українські товариства продовжують свою діяльність. Громадські об'єднання української діаспори або ж висловлюють підтримку проєвропейським змінам в нашій державі або ж займають нейтральну позицію, що опосередковано пов'язано із впливом російських спілок. Негативним $\epsilon$ і занепад українського шкільництва [5, с. 7-8; 10, c. 84-87].

Українсько-російські відносини завжди відігравали важливу роль у зовнішній геополітиці обох держав. Це пов'язано, перш за все, зі спільними соціально-політичними та історичними зв'язками. Починаючи 3 XVII ст., наш народ та більшість його земель стали зоною безпосереднього впливу російських великодержавників, а також частиною економічної системи імперії. Навіть у часи національно-визвольних змагань 1917-1920 рр. деякі політичні сили не могли уявити Україну і Росію не інакше як територіальну цілісність. Таку позицію займали більшовики. I навіть із формуванням УРСР як складової Радянського Союзу ніхто не уявляв реальної можливості збереження засад самостійності. Всіма силами еліти переплітали нашу історію зі східним сусідом.

Росія, із впровадженням доктрини “ближнього зарубіжжя" 90-х рр., хотіла закріпитися на пострадянському просторі, акцентуючи увагу на вже встановлених зв'язках часів СРСР. Тобто постало питання регіональної гегемонії (враховуючи успіхи інтенсифікації у рамках СНД, ОДКБ та ЄврАзЕС). Але українське керівництво завжди намагалося диверсифікувати свої зовнішньополітичні дії, які не знаходили компромісу із російським урядом. Будь-які конкретні кроки суттєвого відходу від проросійської лінії закінчувалися торговими та інформаційними війнами. Остаточною фазою стали події Революції Гідності. Тобто провалилася «консервація» проросійського керівництва, а для зупинки інтенсивної інтеграції у європейські/ євроатлантичні проекти було здійснено військову агресію та анексовано частину території України. Новий уряд дистанціювався від співробітництва 3 Росією на прямому рівні, але вирішив зберегти дипломатичні відносини для захисту прав українців i для ведення переговорів щодо визволення політичних в'язнів. Офіційно діалог на вищому рівні ведеться в Нормандському форматі за участі лідерів Німеччини та Франції, тобто стосунки перейшли на глобальний рівень, хоча такими вони стали ще від прийняття Резолюції щодо Криму із засудженням дій Росії більшістю держав світу. Згодом було введено санкції проти нашого східного сусіда за невиконання міжнародних зобов'язань [34, с. 7-14]. На сьогодні дії російського керівництва $є$ найбільшою загрозою геоекономічній діяльності нашої держави. Впровадженні санкції обмежують використання транспортно-логістичної системи Росії для виходу на азійські ринки. Щодо двосторонніх взаємин, оскільки російсько-українська війна майже ніде не закріплена 
у документах офіційно, торгівля 3 Росією і надалі продовжується. 32011 р. (найвищої точки обігу) до 2018 р. обсяг експорту товарів скоротився більш ніж в п'ять разів, а частка Росії в експорті знизилася з 26,3\% до 7,0\% відповідно. Зниження відбулося у вивезенні продукції машинобудування через обмеження поставок вагонів. Експорт металургії суттєво знизився в умовах падіння внутрішнього виробництва. Продовольче ембарго 2016 р. з боку російського уряду звело нанівець торгівлю харчовою продукцією. В даному контексті збільшення стосуються поставок металургії, які можуть здійснювалися з підприємств, що належать російським індустріально-промисловим групам. 32012 р. до 2018 р. обсяг імпорту товарів РФ скоротився п'ять разів, а його частка у загальному імпорті товарів знизилася з 36,3\% до 6,4\% відповідно. Останнє підняття товарообігу у 2018 р. пов'язано не так із збільшенням поставок 3 України до Росії чи навпаки, а зі збільшення світових цін на деяку продукцію. Скорочення імпорту в останні п'ять років, насамперед, зумовлено поступовою відмовою від постачання газу, на який раніше припадала майже половина імпорту. Серед товарів, які досі важко замінити, можна виділити вугілля та ТВЕЛи. Стійкість продемонстрував імпорт хімічної продукції з Росії через нестабільну роботу вітчизняних підприємств хімічної промисловості [3, с. 26-32]. Геокультурний аспект має значні деструктивні тенденції відносин, до яких призвела інформаційна війна, що полягає у дискредитації політико-географічних процесів в Україні. Крім того, спостерігаються утиски українців у самій Росії. Вражає нахабнеставлення російськихправоохоронців до культурно-просвітницьких закладів, зокрема української бібліотеки в Москві. Існує побоювання щодо функціонування національних товариств наших співвітчизників, адже їх можуть перевіряти на лояльність державі. Чинна влада почала ліквідацію національно-культурних товариств ще з 2012 р., тому проведення просвітницької роботи для збереження ідентичності перебуває під загрозою. Це тільки підкреслює утвердження асиміляційних процесів. Окрім того, важливим чинником $є$ зменшення кількості українців, які живуть в Росії. Згідно 3 переписом 2010 р. у РФ наша діаспора становила 1927988 осіб (1,40\%), і порівняно з 2002 р. знизилася на мільйон [10, с. 91-98]. Діяльність товариств також має негативні моменти, адже війна ліквідувала більшість національних організацій відповідних держав у кожній з них.

В окрему групу доцільно виділити ті країни, які перебувають у сильній геополітичній залежності від регіонального лідера пострадянського простору. Для Білорусі - це, насамперед, геополітична та геоекономічна залежність, адже Росія виступає донором природних ресурсів та основним ринком збуту. Вірменія має схожу мотивацію. Уряд країни має нагальну потребу у військово-політичній та економічній підтримці. Крім того, республіка в оточенні сусідів-недругів - Азербайджану та Туреччини потерпає через постійні історичні суперечки. Грузію та Іран з країною поєднує більше економічний прагматизм, ніж стратегічне бачення взаємовідносин.

На сьогодні Білорусь - головний партнер серед країн СНД. Російська інтервенція сприйнялася керівництвом країни напружено, адже це показало реальні можливості реалізації амбіцій союзника. Та все ж під час голосування щодо Резолюції Генасамблеї ООН 3 приводу цілісності України північний сусід зайняв позицію «проти». Водночас президент країни виступив за єдність нашої держави та абсолютно не сприйняв ідею федералізації. Саме столиця Білорусі стала переговорним майданчиком лідерів України, Росії, Німеччини та Франції щодо мирного врегулювання конфлікту на Донбасі, а також Тристоронньої контактної групи. Нейтралітет Білорусі до всіх подій - найкраща гарантія національної безпеки України, враховуючи союзницькі відносини офіційного Мінська та Москви в межах Союзної держави, ОДКБ та САC [16, с. 157- 158]. У торговельно-економічній сфері в останні роки було ліквідовано наслідки введених раніше торгових мит. Міжурядова комісія зацікавлена в посиленні співпраці, щоб країни мали вигоду від реалізації товарів. Український експорт представлений продукцією аграрного сектору та харчової промисловості, металургійного комплексу, машинобудування, хімічної промисловості. Імпорт 3 Білорусі складають нафтопродукти (очевидно, що російського походження), продукція хімічної промисловості, машинобудування, легкої промисловості. В геоекономічному плані Білорусь стала посередником у перепродажі санкційних товарів ЄС до Росії і навпаки. Ідентичними схемами користується Україна. Також Мінськ став важливим авіагабом, який задовольняє попит російських та українських пасажирів [6, с. 26-32; 16, с. 159]. В контексті геокультурних відносин головну роль відіграє сприйняття подій 2013-2014 рр. білоруським суспільством. Погляди розділилися через значний вплив російських ЗМІ та вкорінену миролюбність після Другої світової війни. Багато хто з білорусів серйозно вважав суспільно-політичні трансформації в Україні “державним переворотом”, а анексію Криму “законною”. Важливою залишається підтримка українського населення. За переписом 2009 р. його чисельність становила 158723 особи (1,67\%), більшість 3 яких мешкала у прикордонних районах [10, с. 64-68; 16, с. 160]. У кожній області діють тільки культурні товариства, адже освітньо-просвітницькі були закриті ще на початку 2000-х рp. авторитарною владою.

Вірменія ніколи не мала стратегічного значення для України серед держав Південного Кавказу. I навіть попри деяку нормалізацію політичних відносин за часів президентства В. Януковича кардинальної зміни ситуації не відбулося. Значною мірою на це впливає низка чинників, серед яких розбіжності з приводу статусу Нагірного Карабаху; відсутність підтримки вірменською делегацією в ООН резолюцій щодо територіальної цілісності України та порушення прав людини в Криму; різнобічність геостратегічних напрямків зовнішньої 
політики. Наразі маємо відсутність контактів між лідерами України та Вірменії [1, с. 76-77]. Мирний характер демократичних перетворень 2017-2018 рр. та прихід до влади нових прогресивних сил в уряд на чолі із прем'єр-міністром Ніколою Пашиняном не відобразилися на двосторонніх відносинах. Що стосується геоекономіки, то контакти вкрай рідкісні, оскільки наш уряд розраховує на налагодження тісних зв'язків в ГУАМ, яка виключає Вірменію з цих процесів. Точкою дотику для співпраці залишається можливість використання транспортно-логістичної системи для виходу на ринки Ірану. Показники торговельно-економічної співпраці вкрай низькі і постійно зменшуються (від 225 млн до 175 млн дол. США). Основними експортними товарами є металургійна, хімічна, сільськогосподарська продукція й обладнання, зернові культури. Імпортними $\epsilon$ продукція електрохімічної промисловості, товари харчової галузі та алкогольні напої [21]. Найбільшою перепоною в геокультурному вимірі виступає проблема сприйняття геноциду вірменського народу турками. Відсутність однозначної позиції України (яка мала Голодомор) щодо вірменської трагедії також не сприяє інтенсифікації взаємодії. Наш уряд не хоче псувати тісні контакти iз Туреччиною та Азербайджаном. Міждержавне культурно-гуманітарне співробітництво наразі єднає країни. Цьому сприяє діяльність посольства, яке розтлумачує суть суспільно-політичних трансформацій в Україні [1, с. 78-79]. Громада наших співвітчизників представлена у кількості 1176 осіб згідно з переписом 2011 р. [10, с. 68-69], що унеможливлює іï використання як “м'якої" сили. На жаль, українці дотримуються певної культурної дистанції щодо титульної нації і постійно зближуються 3 російською діаспорою. Вірменська ж діаспора в Україні $є$ дієвим інструментом конструктивної дипломатії.

Держави Центральної Азії завжди були зоною торгово-економічних інтересів України. Ще 3 радянських часів звідси постачалася сировина для підприємств легкої промисловості, а в регіон - продукція машинобудування та кваліфіковані робітники. Для цих країн характерне більш нейтральне ставлення до суспільно-політичних змін в Україні. Офіційні особи намагалися утриматися від коментарів або обмежувалися загальними закликами до збереження миру. Під час голосування за Резолюцію про територіальну цілісність України Казахстан та Узбекистан “утрималися", а Киргизстан, Таджикистан і Туркменістан були “відсутні” [12, с. 107].

Казахстан - основний політичний і торговоекономічний партнер нашої держави, який завжди сприймався керівництвом як регіональний лідер. Після легітимізації влади в Україні у жовтні 2015 р. відбулася зустріч президентів країн. Крім вирішення нагальних проблем економічної співпраці, лідер Казахстану підтримав розвиток Мінського процесу. Геоекономічно транспортна система Центральної Азії має сприяти ліпшому виходу на ринки Китаю, Індії, Пакистану, Ірану i далі. 3 обмеженням транзиту Росією та їі впливом на керівництво країни контакти дещо звузилися. За два роки обіг торгівлі обвалився майже у 2 рази - до позначки 1 млрд 056 млн, а в минулому році дійшов до несприятливих 924 млн дол. США. В основі експорту домінували продовольство та продукти хімічної промисловості, a в імпорті - нафтопродукти, кам'яне вугілля, цинк, сірка, мінеральні добрива [27]. Після розпаду СРСР уряд почав проводити політику збільшення чисельності титульної нації та підвищення іiї ролі у державному будівництві. Відповідно, слов'янські функціонери почали втрачати вплив. Наразі в країні згідно зі статистичними дослідженнями 2016 р. кількість українців становить 289724 осіб. Процеси депопуляції безупинні. Головним представником республіканського рівня $є$ "Рада українців Казахстану”, яка представлена обласними, районними та міськими громадами. Проблемою залишається зросійщення наших співвітчизників [17, c. 182-184].

Узбекистан також здавна приваблював українських політиків та бізнесменів як країна 3 потужним природно-ресурсним потенціалом та великим ринком збуту. Під час загострення військово-політичної ситуації в Україні заява МЗС країни мала стриманий характер стосовно мирного врегулювання і не містила жодної згадки про Росію та її підтримку. У 2015 р. президент Іслам Карімов висловлював невдоволення відсутністю глави України на самітах СНД і небажанням вести діалог, що призвело до стагнації міждержавних політичних відносин. Українсько-узбецьке торгово-економічне співробітництво здійснюється відповідно до Угоди про ЗВТ СНД. Основними статтями експорту $є$ продукти хімічної промисловості, машинобудування, аграрного сектору й фармацевтики. Імпорт із Узбекистану представлений продукцією хімічної та металургійної промисловості, а також легковими автомобілями [17, с. 182-184]. На території держави,за оцінними даними українського посольства, проживає 86854 українці. Сформована ще $з$ радянських часів інтелігенція країни сформувала шість культурних центрів, зокрема "Славутич" та "Надія" із регіональними філіями.

Туркменістан 31995 р. затвердив статус нейтральної держави, тому уряд країни ніколи не робить різких кроків у міжнародному політичному житті. Делегація в ООН під час голосування за вже неодноразово згадувану Резолюцію була відсутня. Після зустрічі президентів у 2016 р. сторони підтвердили вірність принципам рівноправ'я, поваги до суверенітету інших держав та права вибору самостійної моделі розвитку. Міждержавні економічні стосунки базуються на Договорі про довгострокове торгово-економічне співробітництво від 2011 р. Ще у кінці 90-х - на початку 2000-х pp. Україна була одним із головних імпортерів туркменського газу, але оскільки Росія хотіла контролювати всі енергетичні логістичні процеси у межах СНД, то почала купувати вуглеводні країни за заниженими цінами і перепродавати їх європейському (в т.ч. українському) споживачу. 
Згодом через це товарообіг відіграв меншу роль i поступився у загальному обігу наданих послуг. Українські суб'єкти господарювання залучені до будівництва масштабних інфраструктурних об'єктів державного значення, інженерних комунікацій, об’єктів нафтогазоносної, промислової та транспортної галузей. Загалом, торговельний обіг упав із 1 млрд 158 млн (2011) у три рази - майже до 490 млн у 2015 р. Після незначного росту до 2016 р. спав до позначки 297 млн в минулому році. Попри невтішні результати, перспективи налагодження $€$ сприятливими, адже Україна до 2016 р. мала позитивне сальдо торгівлі та стрімке збільшення доходів від наданих послуг [17, с. 182-185; 29]. У геокультурномувимірі двостороннєспівробітництво має непогані тенденції, особливо це стосується вищої освіти та мистецьких заходів. Між університетами країн підписані договори про співпрацю, а в Україні навчається багато туркменських студентів. Щодо діаспори, то станом на 2013 р. в країні проживало не менше 11 тисяч українців. Причинами різкого зниження їхньої чисельності є особливості ведення етнічної політики в Туркменістані та росіянізації співвітчизників [17, с. 185].

Киргизстан має подібні історичні віхи побудови демократичного суспільства. Офіційна позиція керівництва, незважаючи на геополітичну та геоекономічну залежність від уряду Росії, засудила “будь-які дії спрямовані на дестабілізацію ситуації в Україні”. Однак чіткої політики щодо територіальної цілісності не виражено через відсутність делегації під час голосування за відповідну Резолюцію. Негативно українською владою був сприйнятий візит 2017 р. на територію Криму парламентарів від Соціалдемократичної партії Киргизстану, що здійснювався у невідповідному порядку до законодавства України [12, с. 114]. Торгово-економічне співробітництво має незначні показники, але в геоекономічному значенні Киргизстан може бути одним із майданчиків виходу на китайський ринок. Реалізація діяльності суб’єктів торгівлі складає від 160,2 млн. дол. США, а за даними минулого року вона впала більше, ніж у 4 рази до 33,2 млн. Наша держава експортує продукцію харчової промисловості, електричних машин та фармацевтики. Основний імпорт тютюн та похідні вироби. У структурі киргизького експорту Україна займає тільки $0,8 \%$, що говорить про відсутність стратегічності відносин [17, с. $182-$ $184 ; 24]$. У геокультурному плані значний внесок в інтенсифікацію стосунків привнесла реалізація мистецьких проектів та популяризація української культури. Перепис 2009 р. свідчить про наявність в Киргизстані 21924 українців. Тенденції депопуляції вкрай швидкі, чому сприяють, зокрема, значні асиміляційні процеси в діаспорі [10, с. 80-81].

Таджикистан серед усіх країн Центральноазійського регіону відзначається найменшою кількістю контактів 3 Україною. Та все ж влада республіки засудила застосування сили під час Революції Гідності. На затвердженні Рішення ООН щодо цілісності України делегація не була присутньою. Стримана позиція уряду має у собі історичне підгрунтя - громадянську війну на початку 90-х рр., опосередковані наслідки якої відчуваються і досі. Крім того, не варто нехтувати й значним російським впливом [17, с. 185]. Українськотаджицька економічна співпраця не має вагомих показників через географічну віддаленість та незначну вигоду від виходу на ринок. Від початку дії ЗВТ СНД активізувалися контакти на рівні лідерів. Відбулося залучення українських підприємців в інфраструктурні проекти, головно малої енергетики. Експорт представлений продукцією харчової та фармацевтичної промисловості, електричних машин тощо. Продуктами імпорту виступає сільськогосподарська продукція (плоди, горіхи, насіння). Звичайно, така структура не розширить стосунки до реального партнерства [28]. Культурногуманітарне співробітництво немає широкого представлення серед двох народів. Єдиний вартісний проект - проведення Днів українською культури в Таджикистані, і навпаки. Наша держава надає стипендії таджицьким студентам, що є фундаментом освітніх взаємин. Динаміка чисельності українців загалом катастрофічна. До розпаду СРСР в республіці українців налічувалося 41375 осіб, а у 2010 р. - лише 1090 осіб [10, с. 109]. Передусім, таке зменшення чисельності українців можна пояснити рееміграцією на Батьківщину, природним скороченням та зміною національної належності. Зважаючи на малочисельність української діаспори, наступний перепис може зафіксувати маленьку групу українців, яку не можна буде окреслити вище наведеним широким поняттям.

Аналіз геополітичних, геоекономічних та геокультурних процесів на пострадянському просторі та конкретно у відносинах 3 кожною країною Східної Балтії та СНД дозволяє більш комплексно сприймати міждержавні відносини України. Співставлення загальних політикогеографічних процесів і безпосередніх стосунків дає змогу конкретніше сформувати конструктивну геостратегію, яка повинна враховувати взаємовигоди всіх суб'єктів. Суспільно-політичні трансформації в Україні та нові геополітичні реалії, спровоковані Росією, мають вносити свої корективи. Головними партнерами для остаточної реалізації європейських та євроатлантичних процесів в Україні, є, перш за все, країни Східної Балтії, а також уже асоційовані члени Європейського Союзу, що є учасниками ГУАМ.

Конструктивна геостратегія щодо держав Східної Балтї має полягати у реалізації якомога максимальної інтенсифікації політичних та економічних зв'язків для виходу на ринки цих держав та Північної Європи (головно Швеції та Фінляндіï); формуванні міждержавних програм щодо вивчення досвіду реформування політичної та економічної системи у відповідності з європейськими нормами; вивченні досягнень виборчої системи, особливо Естонії; продовженні удосконалення роботи інфраструктурних проектів транспортного маршруту "Viking" в поєднані 3 "Новим шовковим шляхом” Китайської Народної Республіки, а також сприянні формуванню залізничної вісі 
"Київ - Чернігів - Гомель - Мінськ-Вільнюс Рига-Таллінн” для пасажирського сполучення “5-ти столиць", у здійсненні електрифікації для швидкісного вантажного перевезення; захисті національно-культурних прав українців, особливо у Латвії та Естонії, адже саме в цих державах нашим співвітчизникам важко отримати громадянство; сприянні академічних обмінів у престижні виші для формування нової інтелектуальної еліти України.

Геостратегія Української держави має приділяти

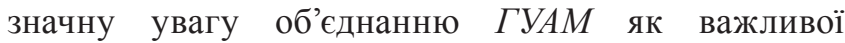
регіональної структури на пострадянському просторі. Нагальне питання - чітка політична підтримка кожного члена та реалізація зони вільної торгівлі, яка сприятиме інтенсифікації обігу товарів і послуг не тільки держав-учасниць, але і сприятиме трансчорноморському з'єднанню країн ЦентральноСхідної Європи та Південного Кавказу. У рамках об'єднання ГУАМ Україні потрібно враховувати специфіку кожного члена об'єднання. Зокрема, у відношенні до Грузї - нівелювання політичної “прохолоди”, пов'язаної з перебуванням представників колишньої еліти в Україні та їхньою діяльністю; обмін досвідом для розробки стратегії щодо окупованих територій у політичному, військовому та соціально-економічному плані; узгодження політики взаємодії в рамках Угоди про асоціацію з $С С$; розвиток сучасного паромного сполучення портів Одеси та Чорноморська із Батумі та Поті для формування трансчорноморського шляху сполучення; підтримка культурно-мистецьких заходів і відродження хоча б класів із навчання українською мовою.

Важливим продовженням такої співпраці $\epsilon$ вдосконалення контактів 3 Азербайджаном, яке полягатиме у продовженні політичного діалогу 3 президентом І.Алієвим 3 чіткою підтримкою територіальної цілісності країни та закликом до нейтрального сприймання подій в Україні (підтримка малоймовірна через тиск Росії); реалізації енергетичних проектів, зокрема експорту до України нафти й газу із залученням готової інфраструктури Грузії, а також модернізації національної; увазі до азербайджанських інвестиційних проектів в Україні та наданні захисту стосовно формування геологістичних умов виходу на ринки ПівденноЗахідної Азії; зміцненні культурно-гуманітарної співпраці, створенні сприятливих умов членам діаспори для реалізації культурних прав, а також освітнім обмінам студентами двох країн.

Побудова стратегії відносно Молдови має геополітичну складність 3 останнім сплеском проросійських сил (це стосується обраного президента Республіки, а також Соціалістичної партії до парламенту). У таких умовах надзвичайно важливо проявити підтримку всіх проєвропейських об'єднань та шукати нових “точок дотику” в межах євроінтеграції. Крім того, важливою залишається потреба вирішення низки проблем між нашими країнами, які стосуються остаточного вирішення питань делімітації та демаркації міждержавного кордону і статусу Дністра; продовження спільної розбудови прикордонної інфраструктури на ділянці з Придністров'ям для контролю переміщення людей, товарів та послуг; сприяння урегулюванню статусу Придністровського квазіутворення та підвищення безпеки кордону Одещини; моніторингу політичних процесів у Гагаузькій автономії; вирішення економічних питань щодо мита на продукти харчування та алкогольні напої; формування спільної енергетичної системи для включення її у відповідну європейську мережу; сприяння транскордонному економічному, соціальному та екологічному співробітництву; налагодження військово-політичної та військово-технічної співпраці; узгодження політики щодо НАТО; нормалізації культурногуманітарних зв'язків, зокрема в шкільній освіті.

Найскладнішою $є$ побудова відносин 3 Російською Федерацією, адже війна завжди вносить у цей процес свої корективи. Тому сподіватися лише на міжнародну підтримку недостатньо, оскільки дії російського керівництва часто непередбачувані. Маємо нагальну потребу у таких кроках, як: дотримання усіх міжнародних зобов'язань щодо окупованих територій для нівеляції будь-яких закидів; підтримка дипломатичних відносин на нейтральному рівні (вони мають зводитися лише до захисту інтересів українців у РФ та вирішення питань щодо військовополонених); сприяння налагодженню контактів із проукраїнськими опозиціонерами; диверсифікація економічних зв'язків 3 Росією 3 якнайшвидшим виходом на ринки Європи та всіх регіонів Азії, законодавчий тиск на підприємства, які працюють 3 підприємствами країни-агресора, але зі сприянням торгівлі 3 іншими країнами; сприяння розвитку обхідних транспортних шляхів; вирішення всіх суперечок на рівні міжнародних організацій. Для забезпечення національної безпеки необхідно активно продовжувати реалізацію оборонного проекту “Стіна", довести функціонування Збройних Сил до стандартів НАТО, а також сприяти виведенню у російський інформаційний простір антипропагандистських програм.

Не меншу увагу слід приділити союзникам Росії, особливо північній сусідці - Білорусі. Історично білоруси найближчий до українського народ, а тому підтримка дійсно дружніх стосунків є важливою для реалізації співпраці на всіх рівнях. Станом на 2019 р. нагальним у двосторонніх відносинах є: збереження дружніх стосунків між президентами держав; продовження підтримки в рамках "Мінського процесу"; сприяння формуванню нейтрального статусу Білорусі в російсько-українському конфлікті, а в перспективі - зміцненню цього статусу на міжнародній арені (формула "Чим далі Білорусь від Росії, тим ближче вона до України”); реалізація останніх погоджень в економічній та культурногуманітарній співпраці, зокрема вже вдалепроведення Форумів регіонів у Гомелі та Житомирі; просування спільних інфраструктурних проектів, нагально електрифікація залізниці від Чернігова до Гомеля, що дозволить вивести на новий рівень проект потягу “п’яти столиць” та розширити логістичні можливості для вантажів по вісі Чорне море - Балтійське море; промоція культурних проектів із залученням 
української діаспори, зокрема мовних курсів.

Цілком зрозуміло, що складніше буде налагодити конструктивну співпрацю 3 іншою російською союзницею - Вірменією, адже геополітичні та геоекономічні інтереси двох держав дуже різні. В політичну площину може увійти соціально-культурна взаємодія, адже народи ставляться досить прихильно один до одного, плюс спостерігається стимулювання експорту й імпорту товарів і послуг. Також доцільним лишається орієнтація на пакет двосторонніх угод та програму СС “Партнерство заради миру”; вироблення нової стратегії щодо історичного минулого вірмен; налагодження хоча б декларативних контактів на рівні глав держав; захист національно-культурних прав українців та реалізація освітніх програм.

Географічною цілісністю та своєрідною геополітичною конструкцією на сьогодні для України мають стати держави Центральної Азї. Актуально збільшити увагу на формуванні регіонального лідерства Казахстану. У подальших відносинах конструктивне значення матиме: спільна позиція щодо дотримання Росією зобов'язань COT на принципах недискримінації 3 відміною транзитної блокади для підвищення торгівлі; участь вітчизняних компаній у Державній програмі із форсованого індустріально-інноваційного розвитку Казахстану на 2015 - 2019 рр.; реалізація спільних проектів в енергетичній сфері, а також видобування корисних копалин; піднесення ролі української діаспори для нівеляції російського геокультурного впливу на півночі країни. Другим важливим партнером виступає Туркменістан. Природно-ресурсний потенціал країни з постійним прагненням його використання для господарського розвитку має формувати прагматичні економічні погляди українських можновладців та бізнесструктур. Також республіку цікавить наш науково-технічний потенціал, можливості купівлі різноманітних послуг за дешевшою ціною. Надалі варто наголошувати на політичній волі нашої країни щодо статусу Каспійського моря для реалізації Трансчорноморсько-КавказькоКаспійського транспортного коридору в обхід Росії; сприяти виходу українських фірм на туркменський ринок будівельних послуг та участі нашої держави у розробці корисних копалин; посилювати співробітництво в культурно-гуманітарній сфері, особливо через академічні обміни. Третім за важливістю суб'єктом є Узбекистан, який відзначається найбільшим людським потенціалом. Стратегія України має базуватися на збільшенні товарообігу для збереження сталої динаміки; потребі безпосереднього діалогу 3 президентом Шавкатом Мірзійоєвим, який все ж таки лібералізує внутрішню та зовнішню геополітику Узбекистану; ліквідації стагнації контактів торгово-промислових палат; запроваджені проектів обміну в науковотехнічній сфері. Попри географічну віддаленість, Киргизстан є цікавим для України як держава демократичного вибору та ринок збуту продукції 3 перспективою виходу на терени Китаю. Надалі доречно встановити нові контакти 3 президентом
Сооронбаєм Жеенбековим; спробувати вийти на ринок інфраструктурних проектів гідроенергетики та видобутку корисних копалин; інтенсифікувати товарообіг; курувати мистецькі проекти, а також реалізовувати “м'яку силу” української діаспори у демократичному суспільстві. Щодо Таджикистану, то тут стратегія має бути ідентичною до киргизстанської, хоча корелюючими факторами мають слугувати стрімке зменшення чисельності української діаспори та вкрай низький рівень розвитку демократії. Актуальним залишається проведення міждержавного культурного та освітнього співробітництва.

\section{Висновки}

Пострадянськийпростір якполітико-географічне утворення має суперечливе значення. Науковці порізному відносяться до даного трактування. Одні вбачають у ньому закономірну цілісність, а інші відносну - через відсутність суттєвих історичних, політичних та економічних зв'язків. У цьому понятті лише один вагомий чинник спільності - перебування у Радянському Союзі, адже геополітичні зв'язки більшості суб'єктів різнобічні. До того, між деякими країнами простору існує незначне торгово-економічне і культурно-гуманітарне співробітництво. Однак, Україна має хорошу договірно-правову базу для взаємовідносин з усіма державами СНД та Східної Балтії і повинна максимально використовувати цю перевагу для поліпшення торгово-економічної діяльності задля збереження вже сталих ринків.

Політико-географічні процеси на пострадянському просторі відбувалися різним чином, зокрема реінтеграційні пов'язані зі створенням СНД та намаганням зберегти сформовані політичні та господарські зв'язки; дезінтеграційні - iз геополітичними векторами розвитку суб'єктів та все меншою важливістю міцних контактів із пострадянськими республіками; інтеграційні - зі створенням організацій 3 домінування російського впливу, наприклад, СврАзЕС (трансформований у Євразійський економічний союз), військовополітичний блок ОДКБ. Для України таким у даному контексті $\epsilon$ утворення ГУАМ (як регіональної політичної організації) та ЗВТ СНД (як можливості розширення економічної взаємодії). Для розуміння формування наявних політико-географічних процесів було виділено етапи їх перебігу. Основним у даному дослідженні став останній, пов'язаний із російською інтервенцією в Україну. Однозначно, що це надзвичайно вплинуло на двосторонні відносини iз кожним суб'єктом. Ліпші політичні контакти налагоджуються із державами Східної Балтії (члени ЄС та НАТО), країнами ГУАМ. Натомість, через транспортну блокаду Росії та політичний тиск їі уряду на керівництво держав регіону порушилися торгово-економічні зв'язки з державами Центральної Азії, які мають бар'єрне сполучення Росією. До мінімуму зведені контакти із союзницею Вірменією, адже торгово-економічне співробітництво наразі перебуває у стагнації, а політичні контакти майже 
відсутні. Минулорічні протести 3 наступними демократичними перетвореннями не дали нового імпульсу у двосторонніх взаєминах. Відносини ще 3 однією союзницею Росії-Білоруссю мають динамічні тенденції. Країна важлива як економічний партнер, a iii керівництво сприяє формуванню майданчика переговорів щодо врегулювання конфлікту на Сході України. Найтяжча побудова відносин із ворожою державою - Російською Федерацією. Рішення кремлівських еліт щодо вторгнення в Україну звели нанівець українсько-російські відносини. Позитивних стосунків у політичному, економічному, соціально-культурному не слід чекати навіть за врегулювання конфлікту. Міжлюдські контакти так само порушені агресивними постімперськими геополітичним настроями їхньої влади. Особливо, коли російські діячі культури i звичайні громадяни сприймають рішення їхнього уряду як адекватну дію.

Щоб відповісти на всі геополітичні виклики, сформовані суспільно-політичними трансформаціями 2013-2014 рр., маємо нагальну потребу у розробці конструктивної геостратегії щодо держав пострадянського простору 3 урахуванням усіх реалій. Основний акцент при цьому ставиться на інтенсифікації двосторонніх відносин, особливо 3 державами Східної Балтії (члени СС та НАТО) й
ГУАМу (всі, крім Азербайджану - асоційовані члени ЄC). Посилення торгово-економічних контактів можливе через тиск міжнародних торговельних та фінансових структур (МВФ, СОТ і т.д.) на Росію, а також із розвитком обхідного транспортного коридору Чорним морем, державами Південного Кавказу та Каспійським морем. Актуальним питанням для українського керівництва залишається збереження та розвиток національно-культурних товариств та запевнення безпеки їх функціонування.

Існування думок, що повне розірвання стосунків iз державами СНД (“сателітами Росії) сприятиме європейському поступу, є деструктивним. Наявність різних геополітичних векторів розвитку деяких країн не повинна позначатися на вигідності торгово-економічного співробітництва. Такий меседж керівникам республік повинен передаватися на постійній основі. Україні варто доносити свою позицію міжнародному співтовариству, формувати позитивний геополітичний образ, а завдяки реалізації реформ всередині країни в перспективі ставати конструктивно пов'язаною ланкою між країнами СС та СНД (особливо для тих, які прагнуть демократичних перетворень). А це породжує необхідність залучення у дослідження фахівців в галузі історії, права, міжнародних відносин, i звичайно, географії.

\section{References:}

1. Avetisyan L. V. Geneza ta perspektiva virmeno-ukrayinskogo spivrobitnitstva [Genesis and development prospects of Armenian - Ukrainian cooperation]. Zhurnal "Politychne zhyttia". DonNU imeni Vasylia Stusa [«Political life» Vasyl' Stus Donetsk National University], 2017, vol. 4, pp. 75-80. (In Ukrainian).

2. Azerbaidzhan i Ukraina: spilnist dol, vidminnosti postupu, shliakhy vzaiemodii [Azerbaijan and Ukraine: common destinies, differences of progress, ways of ineraction]. Ukrainskyi sotsium [Ukrainian society], 2014, N. 4, pp. 7-26. (In Ukrainian).

3. Analiz tendentsii zovnishnoi torhivli tovaramy Ukrainy i tovarnymy hrupamy [Analysis of trends in foreign trade in goods of Ukraine and commodity groups]. Departament monetarnoi polityky ta ekonomichnoho analizu [Department of monetary policy and economic analysis]. URL: https://bank.gov.ua/doccatalog/document?id=50356637 (In Ukrainian).

4. Betlii O. Audyt zovnishnoi polityky: Ukraina-Lytva: dyskusiina zapyska [Audit of foreign policy: Ukraine Lithuania: discussion note]. Kyiv: Instytut Svitovoi polityky [Institute of world policy], 2016. URL: https://glavcom. ua/pub/pdf/49/4935/audytlytvaukraine.pd (In Ukrainian).

5. Betlii O. Audyt zovnishnoi polityky: Ukraina-Moldova: dyskusiina zapyska [Audit of foreign policy: Ukraine - Moldova: discussion note]. Kyiv: Instytut Svitovoi polityky [Institute of world policy], 2016. URL: https:/glavcom. ua/pub/pdf/49/4935/auditukrmol.pdf (In Ukrainian).

6. Betlii O., Preiherman Ye. Audyt zovnishnoi polityky: Ukraina-Bilorus: dyskusiina zapyska [Audit of foreign policy: Ukraine - Belarus: discussion note]. Kyiv: Instytut Svitovoi polityky [Institute of world policy], 2016. URL: https://glavcom.ua/pub/pdf/10/1068/1.pdf (In Ukrainian).

7. Haidai D. Audyt zovnishnoi polityky: Ukraina - Hruziia: dyskusiina zapyska [Audit of foreign policy: Ukraine - Geogia: discussion note]. Kyiv: Instytut Svitovoi polityky [Institute of world policy], 2016. URL: https:/glavcom.ua/ pub/pdf/49/4935/auditukrgeo.pd (In Ukrainian).

8. Herasymchuk S. Ukraina ta Moldova - novi vyklyky ta mozhlyvosti u dvostoronnikh vidnosynakh [Ukraine and Moldova - new challenges in bilareral relations]. Fond imeni Fridrikha Eberta [Friedrich Ebert Stiftung]. URL: http:// library.fes.de/pdf-files/bueros/ukraine/13907.pd (In Ukrainian).

9. Dnistrianskyi M. S. Politychna heohrafiia ta heopolityka Ukrainy: Navchalnyi posibnyk [Political geography and geopolitics of Ukraine: Textbook]. Ternopil: Navchalna knyha - Bohdan Publishing House, 2010,344 p. (In Ukrainian).

10. Zubyk A. I. Suchasna ukrayins'ka diaspora: rozselennya, sotsio- i demoheohrafichni protsesy [Modern Ukrainian diaspora: resettlement, socio- and demogeographical processes]: dys. kand. heohr. nauk [PhD dissertation]. Lviv, 2016, 340 p. (In Ukrainian).

11. Koroma N. S. Stanovlennia obiektno-predmetnoi sutnosti politychnoi heohrafii ta heopolityky [Making 
object-subjetessence political geography and geopolitics]. Geopolitika i ekogeodinamika regionov [Geopolitics and Ecogeodynamics regions], 2014, T. 10, Vol. 2, pp. 119-124. (In Ukrainian).

12. Lyashenko T. Rosiys'ko-ukrayins'ki vidnosyny v politychniy dumtsi Tsentral'noyi Aziyi [Russian-Ukrainian relations in political idea of the states of Central Asia]. Naukovi zapysky Instytutu politychnykh $i$ etnonatsional'nykh doslidzhen' im. I. F. Kurasa [Scientific notes of Kuras Institute of Political and Ethnic studies], 2014, vol. 2 (70), pp. 106-120. URL: http://www.ipiend.gov.ua/uploads/nz/nz_70/liashenko_rosiisko.pdf

13. Malskyi M., Kuchyk O. Orhanizatsiia za demokratiiu i ekonomichnyi rozvytok - HUAM yak proekt rehionalnoho liderstva Ukrainy: problemy ta perspektyvy [Organization for Democracy and Econimik Development - GUAM as a project and regional leadership of Ukraine: problems and prospects]. Visnyk Lvivskoho universytetu. Seriia: Mizhnarodni vidnosyny [Visnyk of the Lviv University. International Relations Series], 2013, Vol. 32, pp. 47-54. URL: http://nbuv.gov.ua/UJRN/VLNU_Mv_2013_32_9 (In Ukrainian).

14. Mandzii L. S. Rol krain Prybaltyky u vyrishenni konfliktu v Ukraini [The role of Baltic countries in solving the conflcts in Ukraine]. Mizhnarodni intehratsiini protsesy: istorychnyi dosvid, suchasni vyklyky ta perspektyvy: materialy mizhnarodnoi naukovo-praktychnoi konferentsii [International conference "International integration processes: historical experience, modern challenges and prospect]. Lviv: Soroka, 2015, pp. 202-207. (In Ukrainian).

15. Melnychuk I.M. Intehratsiini proekty Rosiiskoi Federatsii na postradianskomu prostori [Integration projects of the Russian Federation on the Post-Soviet Periphery]: dys. dokt. polit. nauk. 2015, 519 p. (In Ukrainian).

16. Morhatskyi V. Heopolitychni tendentsii Bilorusi na foni suspilnoi i viiskovo-politychnoi kryzy v Ukraini [Geopolitical trends of Belarus on the background of the public/ military and political crisis in Ukraine]. Visnyk Kyivskoho natsionalnoho universytetu. Seriia: Heohrafiia [Bulletin of Taras Shevchenko National University of Kyiv, Geography], 2017, vol. 1-2 (66-67), pp. 155-159. (In Ukrainian)

17. Morhatskyi V. Ukraina i derzhavy Tsentralnoi Azii v novykh heopolitychnykh realiiakh: heoekonomichnyi ta heostratehichnyi aspekty [Ukraine and Central Asia in new geopolitical realities: geoeconomic and geostrategic aspects]. Visnyk Kyivskoho natsionalnoho universytetu. Seriia: Heohrafiia [Bulletin of Taras Shevchenko National University of Kyiv, Geography], 2017, Vol. 3(68) - 4 (69), pp. 180-186 (In Ukrainian).

18. Morhatskyi V. Postradjanskyij prostir jak heopolitychna realnist: osnovni rysy ta novi tendenciji [PostSoviet space as a geopolitical reality: main properties and new trends]. Molodi naukovci - heografichniy nauci: Zbirnyk naukovykh prac XIV Vseukrajinjkoji naukovo - praktychnoja konferenciji studentiv, aspirantiv, molodykh vchenykh [Young scientists to the geographical science: Collection of scientific papers of the XIV All-Ukrainian scientific and practice conference of students, PhDs and young scientists]. Kyiv: "Feniks", 2018, Vol. XIV, pp. 95-99. (In Ukrainian).

19. Orlova T.V. Istoriia postradianskykh krain: pidruchnyk [History of post-Soviet countries: textbook]. Kyiv: Znannia, 2014. 502 p. (In Ukrainian).

20. Official website of the State Statistics Service of Ukraine]. URL: http://www.ukrstat.gov.ua/

21. Official website of the Embassy of Ukraine in the Republic of Azerbaijan. URL: http://azerbaijan.mfa.gov.ua/ua

22. Official website of the Embassy of Armenia in Ukraine. URL: ukraine.mfa.am/ru/

23. Official website of the Embassy of Ukraine in Georgia. URL: http://georgia.mfa.gov.ua/ua

24. Official website of the Embassy of Ukraine in the Republic of Estonia. URL: http://estonia.mfa.gov.ua/ua

25. Official website of the Embassy of Ukraine in Kyrgyzstan. URL: http://kyrgyzstan.mfa.gov.ua/ua

26. Official website of the Embassy of Ukraine in Republic of Latvia. URL: http://atvia.mfa.gov.ua/ua/ukrainelv/trade

27. Official website of the Embassy of Ukraine in Kazakhstan. URL: http://kazakhstan.mfa.gov.ua/ua

28. Official website of the Embassy of Ukraine in the Republic of Moldova. URL: http://moldova.mfa.gov.ua/ua

29. Official website of the Embassy of Ukraine in the Republic of Tajikistan. URL: http://tajikistan.mfa.gov.ua/ua

30. Official website of the Embassy of Ukraine in the Republic of Turkmenistan. URL: http:/turkmenistan.mfa. gov.ua/ua

31. Poltorakov O. Yevraziiskyi rehionalizm: heostratehiia prostoru SND [Eurasian regionalism: geostrategy of the development of the CIS space]. Politychnyi menedzhment [The political management"], 2012, N. 3, pp. 83-91. URL: http://nbuv.gov.ua/UJRN/PoMe_2012_3_11 (In Ukrainian).

32.KhorosheniukS.I.SpivrobitnytstvoUkrainytakrainBaltiivkontekstiyevrointehratsiinykhprotsesiv[Cooperation between Ukraine and the Baltic countries in the context of Europe an integration processes]: dys. kand. polit. nauk [PhD Thesis]. Chernivtsi, 2017, 211 p. (In Ukrainian).

33. Yakhno Olesia Audyt zovnishnoi polityky: Ukraina - Rosii: dyskusiina zapyska [Audit of foreign policy: Ukraine - Russia: discussion note]. Kyiv: Instytut Svitovoi polityky [Institute of world policy], 2016. URL: https://drive.google.com/file/d/0B7i_OSucRX5wRjhCckJrYkhrYW8/view (In Ukrainian).

\section{Список використаних джерел:}

1. Аветісян Л. В. Генеза та перспектива вірмено-українського співробітництва / Л. Аветісян // Журнал «Політичне життя» (ДонНУ імені Василя Стуса. - 2017. - Вип. 4. - С. 75-80.

2. Азербайджан і Україна: спільність доль, відмінність поступу, шляхи взаємодії // Український соціум. - 2014. - № 4. - С. 7-26. 
3. Аналіз тенденцій зовнішньої торгівлі товарами України і товарними групами // Департамент монетарної політики та економічного аналізу. - Режим доступу: https://bank.gov.ua/doccatalog/document?id=50356637

4. Бетлій О. Аудит зовнішньої політики: Україна-Литва: дискусійна записка / О. Бетлій. - Київ, Інститут Світової політики, 2016. - Режим доступу: https:/glavcom.ua/pub/pdf/49/4935/audytlytvaukraine.pdf

5. Бетлій О. Аудит зовнішньої політики: Україна-Молдова: дискусійна записка / О. Бетлій. - Київ, Інститут Світової політики, 2016. - Режим доступу: https:/glavcom.ua/pub/pdf/49/4935/auditukrmol.pdf

6. Бетлій О. Аудит зовнішньої політики: Україна-Білорусь: дискусійна записка / О. Бетлій, Є. Прейгерман. - Київ, Інститут Світової політики, 2016. - Режим доступу: https:/glavcom.ua/pub/pdf/10/1068/1.pdf

7. Гайдай Д. Аудит зовнішньої політики: Україна-Білорусь: дискусійна записка / Д. Гайдай. - Київ, Інститут Світової політики, 2016. - Режим доступу: https:/glavcom.ua/pub/pdf/49/4935/auditukrgeo.pd

8. Герасимчук С. Україна та Молдова - нові виклики та можливості у двосторонніх відносинах / С. Герасимчук // Фонд імені Фрідріха Еберта. - Режим доступу: http://library.fes.de/pdf-files/bueros/ukraine/13907.pdf

9. Дністрянський М. С. Політична географія та геополітика України: навчальний посібник / М. С. Дністрянський. - Тернопіль: Навчальна книга - Богдан, 2010. - 344 с.

10. Зубик А. І. Сучасна українська діаспора: розселення, соціо- і демогеографічні процеси: дис. канд. геогр. наук: 11.00 .02 / А. І. Зубик. - Львів, 2016. - 340 с.

11. Корома Н. С. Становлення об'єктно-предметної сутності політичної географії та геополітики / Н. С. Корома // Геополитика и экодинамика регионов. - 2014. - Т. 10. - Вип. 2. - С. 119-124.

12. Ляшенко Т. М. Російсько-українські відносини в політичній думці Центральної Азії / Т. М. Ляшенко // Наукові записки Інституту політичних і етнонаціональних досліджень ім. І. Ф. Кураса. - 2014. - Вип. 2 (70) - C. 106-120. - Режим доступу: http://www.ipiend.gov.ua/uploads/nz/nz_70/liashenko_rosiisko.pdf

13. Мальський М. Організація за демократію і економічний розвиток - ГУАМ як проект регіонального лідерства України: проблеми та перспективи / М. Мальський, О. Кучик // Вісник Львівського університету. Серія: Міжнародні відносини. - 2013. - Вип. 32. - С. 47-54. - Режим доступу: http://nbuv.gov.ua/UJRN/VLNU_ Mv 2013329

14. Мандзій Л. С. Роль країн Прибалтики у вирішенні конфлікту в Україні / Л. С. Мандзій // Міжнародні інтеграційні процеси: історичний досвід, сучасні виклики та перспективи: матеріали міжнародної науковопрактичної конференції. Національний університет «Львівська політехніка». - Львів: Сорока, 2015. - С. $202-$ 207.

15. Мельничук I. М. Інтеграційні проекти Російської Федерації на пострадянському просторі: дис. докт. політ. наук: 23.00 .04 / І. М. Мельничук, 2015. - 519 с.

16. Моргацький В. Геополітичні тенденції Білорусі на фоні суспільної і військово-політичної кризи в Україні / В. Моргацький // Вісник Київського національного університету. Серія: Географія. - 2017. - Вип. 1-2 (66-67). - С. 155-159.

17. Моргацький В. Україна і держави Центральної Азії в нових геополітичних реаліях: геоекономічний та геостратегічний аспекти / В. Моргацький // Вісник Київського національного університету. Серія: Географія. - 2017. - Вип. 3(68) - 4 (69). - С. 180-186.

18. Моргацький В. Пострадянський простір як геополітична реальність: основні риси та нові тенденції / B. Моргацький. Молоді науковці - географічній науці: Збірник наукових праць XIV Всеукраїнської науковопрактичної конференції студентів, аспірантів, молодих вчених. - К.: Видавництво «Фенікс», 2018. - Вип. XIV. - С. 95-99.

19. Орлова Т. В. Історія пострадянських країн: підручник / Т. В. Орлова. КНУ імені Тараса Шевченка. - К.: Знання, 2014. - 502 с.

20. Офіційний сайт Державної служби статистики України. - Режим доступу: http://www.ukrstat.gov.ua/

21. Офіційний сайт посольства України в Азербайджанській Республіці. - Режим доступу: http://azerbaijan. mfa.gov.ua/ua

22. Официальный сайт посольства Армении в Украине. - Режим доступу: ukraine.mfa.am/ru/

23. Офіційний сайт посольства України в Грузії. - Режим доступу: http://georgia.mfa.gov.ua/ua

24. Офіційний сайт посольства України в Естонській Республіці. - Режим доступу: http://estonia.mfa.gov. ua/ua

25. Офіційний сайт посольства України в Киргизькій Республіці. - Режим доступу: http://kyrgyzstan.mfa. gov.ua/ua

26. Офіційний сайт посольства України в Латвійській Республіці. - Режим доступу: http://atvia.mfa.gov. ua/ua/ukraine-lv/trade

27. Офіційний сайт посольства України в Республіці Казахстан. - Режим доступу: http://kazakhstan.mfa. gov.ua/ua ua/ua

28. Офіційний сайт посольства України в Республіці Молдова. - Режим доступу: http://moldova.mfa.gov.

29. Офіційний сайт посольства України в Республіці Таджикістан. - Режим доступу: http://tajikistan.mfa. gov.ua/ua

30. Офіційний сайт посольства України в Республіці Туркменістан. - Режим доступу: http://turkmenistan. mfa.gov.ua/ua 
31. Полтораков О. Євразійський регіоналізм: геостратегія простору СНД / О. Полтораков // Політичний менеджмент. - 2012. - №3. - С. 83-91. - Режим доступу: http://nbuv.gov.ua/UJRN/PoMe_2012_3_11

32. Хорошенюк С. І. Співробітництво України та країн Балтії в контексті євроінтеграційних процесів: дис. канд. політ. наук : 23. 00. 04 / С. І. Хорошенюк. - Чернівці, 2017. - 211 с.

33. Яхно О. Аудит зовнішньої політики: Україна - Росія: дискусійна записка / О. Яхно. - Київ: Інститут Світової політики, 2016. - Режим доступу: https://drive.google.com/file/d/0B7i_OSucRX5wRjhCckJrYkhrYW8/ view 